Kredo 4 (2021)
KREDO: Jurnal Ilmiah Bahasa dan Sastra
Terakreditasi Sinta 4 berdasarkan Keputusan
Direktorat Jenderal Penguatan Riset dan
Pengembangan, Kementerian Riset, Teknologi dan
Pendidikan Tinggi Republik Indonesia
Nomor: 23/E/KPT/2019.08 Agustus 2019
https://jurnal.umk.ac.id/index.php/kredo/index

\title{
PENGEMBANGAN BUKU TEKS SASTRA BERBASIS KEARIFAN LOKAL PATI UNTUK SMP/MTS
}

\author{
Mujiwanto $^{1}$, Murtono $^{2}$, Irfai Fathurohman ${ }^{3}$. \\ mujiwanto9@gmail.com¹, murtono@umk.ac.id², irfai.fathurohman@umk.ac.id ${ }^{3}$ \\ Universitas Muria Kudus, Indonesia
}

\section{Info Artikel \\ Sejarah Artikel \\ Diterima \\ 3 Desember 2020 \\ Disetujui \\ 8 April 2021 \\ Dipublikasikan \\ 9 April 2021}

\section{Keywords}

textbooks, literature,

learning.

Kata Kunci

buku teks, sastra, pembelajaran.

\section{:}

Abstract

The purpose of this study was to present the test results on research and development of literature textbooks based on local wisdom of Pati as a learning material for Indonesian language in $S M P / M T s$ based on teacher assessments. The method used in this study is the method of $R \& D$. The : reference in this study was adapted from Borg \& Gall. The results showed that (1) teachers need literary textbooks that contain elements of character education and local wisdom. The textbook that the teacher wants as a reference for literature learning is a textbook that is adequate, covers, and is in accordance with the literature learning material at SMP/MTs, (2) based on the results of validation, assessment, and suggestions for improvement of the local wisdom-based literature textbook prototype by experts with a value range of 15-60, the average value is 49.83. So that the literature textbook based on local wisdom is declared feasible and valid, (3) it can be seen that the : existence of the literature textbook based on local wisdom is expected to exist, the teacher hopes that the book can be used immediately. The teacher feels helped by the existence of literature : textbooks based on local wisdom as a supporting reference in learning. Regarding the content, the teacher said that the material in the textbook was considered to have fulfilled all the material taught at SMP/MTs. Meanwhile, the validity of the material in the textbook is considered to have met legality.

\section{Abstrak}

Tujuan penelitian ini adalah memaparkan hasil uji pada penelitian dan pengembangan buku teks sastra berbasis kearifan lokal Pati sebagai materi pembelajaran bahasa Indonesia di SMP/MTs berdasarkan penilaian guru. Metode yang digunakan pada penelitian ini adalah metode R\&D. Acuan dalam penelitian ini diadaptasi dari Borg \& Gall. Hasil penelitian diperoleh bahwa (1) guru membutuhkan buku teks sastra yang mengandung unsur pendidikan karakter dan kearifan lokal. Buku teks yang diinginkan oleh guru sebagai referensi pembelajaran sastra adalah buku teks yang mencukupi, melingkupi, dan sesuai dengan materi pembelajaran sastra di SMP/MTs, (2) hasil validasi, penilaian, dan saran perbaikan prototipe buku teks Sastra Berbasis Kearifan Lokal oleh ahli dengan rentang nilai 15-60, nilai rata-ratanya adalah 49.83. Sehingga buku teks Sastra Berbasis Kearifan Lokal dinyatakan layak dan valid, (3) buku teks Sastra Berbasis Kearifan Lokal sangat diharapkan keberadaannya, guru berharap buku tersebut dapat segera digunakan. Guru merasa terbantu dengan adanya buku teks Sastra Berbasis Kearifan Lokal sebagai referensi penunjang dalam pembelajaran. Mengenai isi, guru menyampaikan bahwa materi di dalam buku teks dianggap telah memenuhi seluruh materi yang diajarkan di SMP/MTs. Kesahihan materi di dalam buku teks dianggap sudah memenuhi legalitas. Kajian terakhir yakni mengenai kemampuan buku teks Sastra Berbasis Kearifan Lokal untuk dipahami. 


Kredo 4 (2021)
KREDO: Jurnal Ilmiah Bahasa dan Sastra
Terakreditasi Sinta 4 berdasarkan Keputusan
Direktorat Jenderal Penguatan Riset dan
Pengembangan, Kementerian Riset, Teknologi dan
Pendidikan Tinggi Republik Indonesia
Nomor: 23/E/KPT/2019.08 Agustus 2019
https://jurnal.umk.ac.id/index.php/kredo/index

\section{PENDAHULUAN}

Proses belajar mengajar selalu memerlukan sarana dan prasarana yang memadai. Salah satu sarana yang utama dalam menunjang proses tersebut adalah buku. Buku merupakan bagian dari kelangsungan pembelajaran. Dengan buku yang baik guru dapat membantu guru dalam melaksanakan pembelajaran secara efektif dan efisien. Buku juga dapat membantu memaksimalkan efektivitas belajar siswa. Jenis buku yang biasa digunakan dalam pembelajaran adalah buku teks atau buku pelajaran. Buku teks digolongkan menjadi dua yaitu buku teks wajib atau paket dan buku teks penunjang. Buku teks wajib adalah buku teks yang diterbitkan oleh pemerintah (Kementerian Pendidikan dan Kebudayaan) yang disebut juga buku paket. Sedangkan buku teks penunjang adalah buku teks yang diterbitkan oleh pihak swasta baik yang ditulis oleh perorangan maupun kelompok. Buku teks wajib diterbitkan dan diberlakukan secara nasional, untuk itu dari segi isi lebih bersifat general. Oleh karena itu, diperlukan buku teks penunjang yang mampu melengkapi kekurangan buku teks wajib.

Pemerintah melalui Kementerian Pendidikan dan Kebudayaan telah menyediakan buku teks pelajaran untuk pendidikan dasar dan menengah dengan program buku murah berkualitas dalam bentuk buku elektronik yang boleh dicetak bebas. Hal ini dikarenakan hak cipta buku adalah milik Kemendikbud. Kebijakan tentang penggunaan buku pelajaran ini sesuai dengan Permendikbud nomor 8 tahun 2016 tentang buku yang digunakan oleh satuan pendidikan dasar dan menengah.

$$
\text { Berdasarkan Permendikbud }
$$

tersebut, buku teks pelajaran yang disediakan pemerintah sesuai nama mata pelajaran yang telah ditetapkan dalam struktur kurikulum masing-masing jenjang pendidikan. Dalam hal ini, untuk tingkat Sekolah Menengah Pertama/Madrasah Tsanawiyah telah disediakan buku teks pelajaran bahasa Indonesia. Di dalam pelajaran bahasa Indonesia dibelajarkan pula sastra. Namun, selama ini belum ada buku teks yang khusus memuat materi dan pembelajaran sastra.

Berdasarkan hasil observasi yang dilakukan peneliti di MTsN 1 Pati diperoleh data bahwa buku teks pelajaran bahasa Indonesia yang digunakan yaitu untuk kelas VII menggunakan buku teks terbitan Kemendikbud edisi revisi 2016, buku teks Marbi terbitan Erlangga edisi revisi 2016, dan buku teks terbitan Intan Pariwara edisi revisi 2016; untuk kelas VIII menggunakan buku teks terbitan Kemendikbud edisi revisi 2017, buku teks Marbi terbitan Erlangga edisi revisi 2017, dan buku teks terbitan Intan Pariwara edisi revisi 2017; dan kelas IX 


Kredo 4 (2021)
KREDO: Jurnal Ilmiah Bahasa dan Sastra
Terakreditasi Sinta 4 berdasarkan Keputusan
Direktorat Jenderal Penguatan Riset dan
Pengembangan, Kementerian Riset, Teknologi dan
Pendidikan Tinggi Republik Indonesia
Nomor: 23/E/KPT/2019.08 Agustus 2019
https://jurnal.umk.ac.id/index.php/kredo/index

menggunakan buku teks terbitan Kemendikbud edisi revisi 2018 dan buku teks terbitan Intan Pariwara edisi revisi 2018. Khusus buku teks terbitan Intan Pariwara hanya digunakan oleh guru sebagai pendamping buku teks wajib.

Sastra merupakan satu bentuk karya seni yang menggunakan bahasa sebagai media penyampaiannya. Sastra merupakan bagian yang tidak dapat dipisahkan dalam materi pembelajaran bahasa Indonesia di SMP/MTs. Ada kecenderungan guru dan siswa menganggap bahwa sastra merupakan materi eksklusif yang hanya dapat dipelajari oleh orang-orang berbakat atau sastrawan saja. Hal inilah yang menyebabkan pembelajaran sastra mengalami kurang diminati. Untuk itu diperlukan media (buku teks) yang tepat agar pembelajaran berjalan dengan lebih baik. Hal ini karena pembelajaran sastra tidak dapat terlepas dari pembelajaran bahasa, begitupun sebaliknya. Sastra harus diajarkan secara komprehensif dengan keterampilan berbahasa, mulai dari menyimak, berbicara, membaca, menulis, dan apresiasi.

Sastra memiliki berbagai genre dan subgenre. Sastra yang diajarkan di tingkat Sekolah Menengah Pertama/Madrasah Tsanawiyah secara garis besar antara lain puisi, prosa, dan drama. Bagi siswa, sastra adalah sebuah karya seni yang akan mengasah imajinasi dan membebaskan siswa untuk berekspresi. Hal yang sering terjadi pada

\section{7 | Jurnal Kredo}

Vol. 4 No. 22021 pembelajaran sastra adalah pembelajaran yang terkesan informal sehingga siswa seakan tidak sedang dalam kegiatan belajar. Oleh karena itu, pembelajaran sastra yang tepat dengan media, dan sumber yang sesuai mampu mengeksplorasi dan mengekspresi bakat, minat, dan kreativitas siswa. Hal ini sering terjadi dalam pembelajaran menulis sastra.

Kurikulum $2013 \quad$ sudah diberlakukan sejak tahun 2014 dan diberlakukan secara nasional sejak 2016. Salah satu bentuk kesiapan pemerintah terhadap pelaksanaan kurikulum adalah diterbitkannya buku siswa (buku paket) dan buku guru sebagai salah satu sarana dalam pembelajaran. Salah satu hal yang dikeluhkan oleh guru adalah buku ajar memuat materi yang kurang dalam sehingga diperlukan buku teks sebagai pendamping dan pelengkap buku ajar. Hal ini senada dengan yang diungkapkan Purwanta (2012: 424) bahwa dewasa ini kedudukan buku teks menjadi semakin sentral dalam proses belajar mengajar karena guru merasa sulit dan berat untuk mengembangkan sendiri materi pelajaran yang diampu, entah karena alasan waktu yang terbatas ataupun tekanan eksternal. Kendala tersebut juga dialami oleh para guru yang mengajar di SMP/MTs khususnya dalam pembelajaran materi sastra. Pasalnya ada perbedaan kurikulum 2013 dengan kurikulum sebelumnya antara lain, adanya 


Kredo 4 (2021)
KREDO: Jurnal Ilmiah Bahasa dan Sastra
Terakreditasi Sinta 4 berdasarkan Keputusan
Direktorat Jenderal Penguatan Riset dan
Pengembangan, Kementerian Riset, Teknologi dan
Pendidikan Tinggi Republik Indonesia
Nomor: 23/E/KPT/2019.08 Agustus 2019
https://jurnal.umk.ac.id/index.php/kredo/index

penyederhanaan materi, penambahan jam pelajaran, dan lain sebagainya.

Kurikulum 2013 menekankan pendidikan-pendidikan karakter dalam setiap pembelajarannya. Salah satu karakternya yakni kearifan lokal. Kearifan lokal sedang digalakkan dalam dunia pendidikan. Kearifan lokal merupakan suatu hal yang dimiliki oleh sebuah kelompok dan diwariskan secara turun-temurun. Aspek kearifan lokal diintegrasikan dalam pembelajaran sebagai upaya penanaman nilai dari kearifan lokal dalam rangka membentuk karakter siswa. Kearifan lokal yang dimaksud di sini adalah kebudayaan, adat, tradisi, dan lain sebagainya. Lebih khususnya kearifan lokal dapat berupa minuman, makanan khas, tarian daerah, lagu daerah, dan masih banyak lagi. Kearifan lokal dijadikan basis dalam pembelajaran dengan maksud agar siswa mengenali daerah tempat tinggalnya, memiliki jati diri, dan tidak meninggalkan kebudayaan daerahnya.

Untuk memperoleh data konkret permasalahan ini peneliti melakukan kegiatan observasi lapangan serta wawancara dengan narasumber guru pada hari Jumat, 26 April 2019 di Madrasah Tsanawiyah Negeri 1 Pati yang berada di daerah Kecamatan Winong. Berdasarkan observasi tersebut, diperoleh data dengan diterapkannya kurikulum 2013 menyebabkan guru kesulitan dalam penyesuaian, baik dalam kesiapan mengajar maupun dalam kesiapan bahan ajar. Guru dituntut untuk memiliki pengetahuan yang luas dalam segala materi, sedangkan buku paket dari pemerintah hanya menyajikan materi yang sederhana. Sehingga, yang banyak dialami oleh guru adalah kesulitan dalam menyampaikan materi yang lebih mendalam di setiap mata pelajaran. Hal itu disebabkan oleh terbatasnya materi baru dan media yang mendukung, khususnya pada materi pembelajaran sastra dalam mata pelajaran Bahasa Indonesia. Pengenalan materi hingga contoh pada pembelajaran sastra menyebabkan guru kesulitan dalam mencari buku yang cocok dengan materi dan tingkatan kelas siswa.

Dari problematika tersebut, peneliti menyimpulkan bahwa buku teks sastra sangat dibutuhkan di sekolah atau madrasah. Dalam pembelajaran sastra guru dan siswa banyak menemui kesulitan, seperti mendapatkan pendalaman materi mengenai berbagai genre sastra, menemukan persamaan perbedaan antargenre sastra, menulis atau memproduksi sastra, membaca sastra, menyimak sastra, mementaskan sastra, mengapresiasi sastra dan masih banyak kesulitan lainnya. Penggunaan buku teks sangat dibutuhkan untuk mempermudah guru dalam menyampaikan materi pembelajaran dan mempermudah siswa menerima materi pembelajaran yang disampaikan guru. Tetapi, penggunaan buku teks yang membahas sastra secara khusus masih 


Kredo 4 (2021)
KREDO: Jurnal Ilmiah Bahasa dan Sastra
Terakreditasi Sinta 4 berdasarkan Keputusan
Direktorat Jenderal Penguatan Riset dan
Pengembangan, Kementerian Riset, Teknologi dan
Pendidikan Tinggi Republik Indonesia
Nomor: 23/E/KPT/2019.08 Agustus 2019
https://jurnal.umk.ac.id/index.php/kredo/index

jarang sehingga guru dan siswa kesulitan dalam pembelajaran.

Buku teks adalah buku pelajaran dalam bidang studi tertentu yang merupakan buku standar, yang disusun oleh para pakar dalam bidang itu buat maksud-maksud dan tujuan instruksional, yang diperlengkapi dengan sarana-sarana pangajaran yang serasi dan mudah dipahami oleh pemakainya di sekolah-sekolah dan perguruan tinggi sehingga dapat menunjang suatu program pengajaran (Tarigan, 2009:13). Dengan begitu, untuk menunjang keberhasilan pembelajaran sastra di SMP/MTs diperlukan buku teks sastra yang memadai.

Kenyataan di lapangan adalah materi yang sudah disediakan di buku paket belum memadai sehingga guru mencari materi tambahan dari beberapa sumber. Salah satu sumber yang digunakan guru untuk mendapatkan materi tambahan adalah internet. Padahal materi yang disajikan di internet belum dapat dipastikan kebenarannya.

Dengan demikian, diperlukan adanya suatu buku teks sastra yang khusus, membahas secara detail dan mendalam, dan juga dapat dipertanggungjawabkan kebenarannya.

Mengacu pada tujuan tersebut maka diperlukan adanya sebuah buku teks sastra yang mempermudah guru dan siswa melaksanakan pembelajaran. Buku teks sastra ini diharapkan mampu meningkatkan hasil belajar siswa.

429 | Jurnal Kredo

Vol. 4 No. 22021
Buku teks sastra yang dikembangkan adalah buku teks sastra Indonesia untuk SMP/MTs berbasis kearifan lokal Pati sebagai materi pembelajaran bahasa Indonesia di Sekolah Menengah Pertama/Madrasah Tsanawiyah. Sebuah buku yang dikemas secara menarik untuk membatu guru dan siswa melaksanakan kegiatan pembelajaran.

Media buku teks sastra dapat mempermudah dan membantu siswa dalam memahami materi yang disampaikan guru berkaitan dengan sastra. Dengan media buku teks ini siswa dapat menemukan hakikat genre-genre sastra yang sesungguhnya sehingga mudah memahaminya. Selain itu, media ini dapat meningkatkan pengetahuan dan rasa cinta siswa terhadap kearifan lokal daerahnya.

Menurut John M. Echols dan Hassan Syadily, kearifan lokal (local wisdom) terdiri dari dua kata: kearifan (wisdom) dan lokal (local). Local berarti setempat, sedangkan wisdom (kearifan) sama dengan kebijaksanaan. Secara umum maka local wisdom (kearifan setempat) dapat dipahami sebagai gagasan-gagasan setempat (local) yang bersifat bijaksana, penuh kearifan, bernilai baik, yang tertanam dan diikuti oleh anggota masyarakatnya. Ini senada dengan pendapat Sartini (2004:111) dalam penelitiannya yang berjudul "Menggali Kearifan Lokal Nusantara Sebuah Kajian Filsafat" menyebutkan 


Kredo 4 (2021)
KREDO: Jurnal Ilmiah Bahasa dan Sastra
Terakreditasi Sinta 4 berdasarkan Keputusan
Direktorat Jenderal Penguatan Riset dan
Pengembangan, Kementerian Riset, Teknologi dan
Pendidikan Tinggi Republik Indonesia
Nomor: 23/E/KPT/2019.08 Agustus 2019
https://jurnal.umk.ac.id/index.php/kredo/index

bahwa kearifan lokal merupakan suatu gagasan konseptual yang hidup dalam masyarakat, tumbuh dan berkembang secara terus-menerus dalam kesadaran masyarakat, berfungsi dalam mengatur kehidupan masyarakat yang sifatnya berkaitan dengan sakral sampai yang profan. Dari beberapa pengertian kearifan lokal tersebut, lokal atau daerah tentulah memengaruhi dalam pengembangan buku teks sastra yang dilakukan oleh peneliti.

Buku teks bahasa Indonesia terbitan Kemendikbud edisi revisi 2017 dan 2018 sudah memasukkan pendidikan karakter secara eksplisit dan implisit khususnya pada teks sastra. Namun demikian, karena buku teks tersebut diperuntukkan bagi siswa SMP/MTs seluruh Indonesia maka nilai kearifan lokal masih sangat sedikit. Hal ini senada dengan pendapat Wibowo dan Gunawan (2015:12) bahwa dalam konteks mengisi peran pendidikan karakter dalam pembelajaran bahasa Indonesia di sekolah, kearifan lokal merupakan pilihan yang tepat guna memediasi penanaman karakter melalui bahan ajar. Untuk itu, peneliti melakukan penelitian dan pengembangan buku teks sastra sebagai sarana pembelajaran dan pendidikan karakter melalui materi dan teks-teks sastra dengan muatan kearifan lokal Pati.

Fahmy (2015) dalam jurnal yang berjudul "Pengembangan Buku Pengayaan Memproduksi Teks Fabel
Bermuatan Nilai Budaya untuk Siswa SMP" memaparkan dua hal besar dan mendasar yang melatarbelakangi penelitian ini, yaitu ketersediaan buku sebagai penunjang kurikulum dan terkikisnya karakter/moral bangsa yang sesuai dengan kebudayaan Indonesia. Kedua masalah ini mampu diatasi oleh pendekatan Content and Language Integrated Learning (CLIL) dan Fabel yang diwujudkan dalam sebuah buku pengayaan. Penelitian ini menggunakan metode research and development. Buku pengayaan memproduksi teks cerita fabel bermuatan nilai budaya untuk siswa SMP dinyatakan efektif guna membimbing siswa dalam memproduksi sebuah fabel dengan muatan nilai budaya. Diharapkan buku pengayaan ini bisa digunakan dalam pembelajaran memproduksi teks cerita fabel. Dengan seperti itu, ketersediaan buku yang memuat pendidikan moral/karakter dapat diatasi. Persamaan penelitian tersebut dengan penelitian ini adalah sama-sama memproduksi dan menggunakan teks fabel yang memuat pendidikan moral dalam pembelajaran di SMP. Perbedaannya adalah nilai-nilai budaya daerah mana, tidak dibatasi dalam penelitian Fahmy.

Berdasarkan pemaparan tersebut maka pada penelitian ini dibahas "Pengembangan Buku Teks Sastra Indonesia untuk SMP/MTs Berbasis Kearifan Lokal Pati sebagai Materi Pembelajaran Bahasa Indonesia di 


Kredo 4 (2021)
KREDO: Jurnal Ilmiah Bahasa dan Sastra
Terakreditasi Sinta 4 berdasarkan Keputusan
Direktorat Jenderal Penguatan Riset dan
Pengembangan, Kementerian Riset, Teknologi dan
Pendidikan Tinggi Republik Indonesia
Nomor: 23/E/KPT/2019.08 Agustus 2019
https://jurnal.umk.ac.id/index.php/kredo/index

Sekolah Menengah Pertama/Madrasah Tsanawiyah".

Tujuan penelitian ini adalah memaparkan hasil penelitian dan pengembangan buku teks sastra Indonesia untuk SMP/MTs berbasis kearifan lokal sebagai materi pembelajaran bahasa Indonesia di Sekolah Menengah Pertama/Madrasah Tsanawiyah berdasarkan penilaian guru.

Penelitian ini dirancang untuk menghasilkan sebuah buku teks yang dapat membantu guru dan siswa dalam pembelajaran sastra. Media ini diharapkan dapat digunakan pada siswa Sekolah Menengah Pertama/Madrasah Tsanawiyah khususnya, dan tidak menutup kemungkinan untuk dikembangkan pada siswa di jenjang pendidikan lain. Selain itu, media ini dapat dijadikan alternatif dalam mengembangkan pengetahuan siswa khususnya dalam pembelajaran sastra.

Bagi guru, penelitian ini dapat mempermudah guru untuk mengajarkan pembelajaran sastra menggunakan buku teks sastra Indonesia untuk SMP/MTs berbasis kearifan lokal Pati sebagai materi pembelajaran bahasa Indonesia di SMP/MTs.

Bagi siswa, buku teks sastra Indonesia untuk SMP/MTs berbasis kearifan lokal Pati sebagai materi pembelajaran bahasa Indonesia di SMP/MTs ini dapat menjadi pengayaan materi sastra dalam upaya memperluas pengetahuan sastra siswa.

\section{1 | Jurnal Kredo}

Vol. 4 No. 22021
Dengan demikian, tuntutan kurikulum 2013 dapat terpenuhi, guru dan siswa menjadi lebih mudah melaksanakan pembelajaran sastra dan pembelajaran tidak lagi terkendala dalam memperoleh materi.

\section{KAJIAN TEORI}

\section{A. Buku Teks}

Buku teks pelajaran dapat diartikan sebagai perangkat operasional utama atas pelaksanaan kurikulum dan buku nonteks pelajaran merupakan sarana pendukung untuk memfasilitasi pelaksanaan, penilaian, dan pengembangan pembelajaran bagi siswa dan pendidik sehingga harus memenuhi kriteria buku yang layak digunakan satuan pendidikan (Permendikbud Nomor 8 tahun 2016).

Salah satu buku dalam dunia pendidikan adalah buku teks. Buku teks mempunyai peranan yang sangat penting untuk kemajuan pendidikan. Buku teks adalah buku yang berisi uraian bahan tentang mata pelajaran atau bidang studi tertentu, yang disusun secara sistematis dan telah diseleksi berdasarkan tujuan tertentu, orientasi pembelajaran, dan perkembangan siswa untuk diasimilasikan (Muslich, 2010:50)

Sementara itu, Kustanto dan Hinduan (2009:3) menyatakan bahwa buku teks (textbook) dapat didefinisikan sebagai sumber informasi yang disusun 


Kredo 4 (2021)
KREDO: Jurnal Ilmiah Bahasa dan Sastra
Terakreditasi Sinta 4 berdasarkan Keputusan
Direktorat Jenderal Penguatan Riset dan
Pengembangan, Kementerian Riset, Teknologi dan
Pendidikan Tinggi Republik Indonesia
Nomor: 23/E/KPT/2019.08 Agustus 2019
https://jurnal.umk.ac.id/index.php/kredo/index

dengan struktur dan urutan berdasarkan bidang ilmu tertentu.

Warso (2016:38) mengungkapkan bahwa, buku teks adalah materi pembelajaran yang disusun dan disajikan secara tertulis sedemikian rupa sehingga pembacanya diharapkan bisa menyerap sendiri materi tersebut. Buku teks dibuat dengan membahas masalah nyata di bidang pendidikan formal pada suatu jenjang pendidikan.

Berdasarkan beberapa pendapat tersebut, dapat disimpulkan bahwa buku teks adalah buku dalam bidang pendidikan yang berfungsi sebagai sumber informasi atau bahan ajar tertulis berupa materi yang digunakan pada satuan pendidikan dasar sampai pendidikan tinggi, disusun berdasarkan struktur dan urutan bidang ilmu tertentu yang bertujuan untuk mempermudah proses pembelajaran.

Dengan begitu, buku teks sastra adalah buku yang memuat materi sastra sebagai satu sumber informasi atau bahan ajar yang digunakan pada satuan pendidikan dasar sampai pendidikan tinggi, disusun berdasarkan struktur dan urutan bidang ilmu sastra yang bertujuan untuk mempermudah proses pembelajaran.

\section{B. Ciri-ciri Buku Teks}

Sebagaimana telah dijelaskan secara umum, buku teks adalah sebuah bahan ajar cetak yang digunakan dalam sebuah kegiatan belajar dengan tujuan membantu pemahaman materi pembelajaran. Karakteristik buku teks secara umum seperti dikemukakan oleh Muslich (2010:60) sebagai berikut:

1. Dari segi isi. Buku teks berisi serangkaian pengetahuan atau informasi yang bisa dipertanggungjawabkan keilmiahannya.

2. Dari segi sajian. Materi yang terdapat dalam buku teks disajikan dengan mengikuti pola penalaran tertentu, sebagaimana pola penalaran dalam sajian ilmiah, yaitu pola penalaran induktif, deduktif, atau kombinasi (induktif-deduktif).

Dari segi format. Buku teks mengikuti konvensi buku ilmiah, baik pola penulisan, pola pengutipan, pola pembagian, maupun pola pembahasannya.

Selain ciri tersebut, buku teks juga memiliki tujuan pembuatan. Buku teks dibuat berdasarkan kebutuhan bahan ajar di sekolah. Buku teks yang baik adalah buku teks yang sesuai dengan tuntutan kurikulum dengan mempertimbangkan kebutuhan siswa, sehingga sesuai dengan karakteristik siswa dan latar lingkungan sosial siswa. Dengan demikian, buku teks dapat membantu siswa dalam memperoleh alternatif bahan ajar di samping bukubuku teks yang tersedia. Selain itu, buku teks juga dapat memudahkan guru dalam melaksanakan pembelajaran.

Buku teks merupakan sebuah alternatif dalam kegiatan pembelajaran. Pembuatan buku teks dapat memberikan 


Kredo 4 (2021)
KREDO: Jurnal Ilmiah Bahasa dan Sastra
Terakreditasi Sinta 4 berdasarkan Keputusan
Direktorat Jenderal Penguatan Riset dan
Pengembangan, Kementerian Riset, Teknologi dan
Pendidikan Tinggi Republik Indonesia
Nomor: 23/E/KPT/2019.08 Agustus 2019
https://jurnal.umk.ac.id/index.php/kredo/index

banyak manfaat, seperti siswa memperoleh bahan ajar yang sesuai dengan kurikulum, siswa tidak bergantung pada buku teks yang tersedia saja, siswa menjadi lebih kaya pengetahuan dengan lebih banyak referensi, dan masih banyak lagi manfaat lain yang didapatkan.

Borg and Gall dalam Sugiyono (2019:28) menyatakan bahwa penelitian dan pengembangan merupakan proses atau metode yang digunakan untuk memvalidasi atau mengembangkan produk. Dalam penelitian ini, yang dimaksud produk adalah buku teks sastra. Sedangkan yang dimaksud pengembangan adalah memperbarui produk yang telah ada sehingga menjadi lebih praktis, efektif, efisian, dan lebih sempurna.

Buku teks yang dikembangkan oleh peneliti merupakan buku teks sastra berbasis kearifan lokal Pati. Ada beberapa jenis kearifan lokal yang ada di Kabupaten Pati: budaya/tradisi sedekah bumi, sedekah laut/lomban, meron, dan megengan; sikap/karakter gotong-royong (sambatan); artefak/produk dan seni pintu gerbang Majapahit, genuk kemiri, petilasan Syeh Jangkung, seni ketoprak, batik bakaran, makanan khas nasi gandul, soto kemiri, dan lain-lain.

\section{METODE PENELITIAN}

Metode yang digunakan pada penelitian ini adalah metode penelitian dan

\section{3 | Jurnal Kredo}

Vol. 4 No. 22021 pengembangan (research and development $/ \mathrm{R} \& \mathrm{D})$. Acuan dalam penelitian ini diadaptasi dari Borg \& Gall dengan tahapan sebagai berikut: (1) tahap pendahuluan yaitu eksplorasi dan menganalisis kebutuhan buku teks Sastra Berbasis Kearifan Lokal Pati sebagai Materi Pembelajaran Bahasa Indonesia di SMP/MTs dari 15 guru SMP/MTs dari 5 sekolah, (2) tahap pengembangan (validasi ahli dilakukan oleh praktisi yaitu guru dan oleh akademisi yaitu dosen, uji coba terbatas dilakukan kepada 10 guru SMP/MTs), (3) tahap revisi produk pasca uji coba. Instrumen penelitian ini adalah (1) data kebutuhan buku teks sastra Indonesia pada guru SMP/MTs, (2) data hasil validasi prototipe oleh ahli untuk mengetahui kelebihan dan kekurangan buku teks, dan (3) data hasil uji coba buku teks sastra Indonesia berbasis kearifan lokal oleh guru untuk mengetahui kesesuaian buku teks dengan kebutuhan guru.

Penelitian ini sampai pada langkah ketujuh karena untuk uji coba secara luas tidak memungkinkan karena adanya Pembatasan Sosial atas dampak Pandemi Covid-19. Hal tersebut juga sejalan dengan pendapat Sukmadinata (2012:187) bahwa untuk peneliti dari program S2 atau penyusunan tesis, penelitian dan pengembangan dapat dihentikan sampai dihasilkan draf final, tanpa pengujian hasil. Hasil atau dampak dari penerapan model sudah 


Kredo 4 (2021)
KREDO: Jurnal Ilmiah Bahasa dan Sastra
Terakreditasi Sinta 4 berdasarkan Keputusan
Direktorat Jenderal Penguatan Riset dan
Pengembangan, Kementerian Riset, Teknologi dan
Pendidikan Tinggi Republik Indonesia
Nomor: 23/E/KPT/2019.08 Agustus 2019
https://jurnal.umk.ac.id/index.php/kredo/index

ada, baik pada uji terbatas maupun uji coba lebih luas.

Skema penelitian dapat digambarkan seperti pada bagan 3.1 berikut.

\section{HASIL DAN PEMBAHASAN}

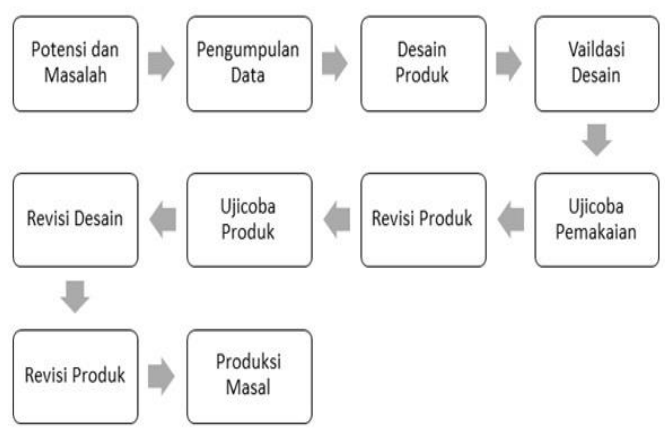

Hasil penelitian ini adalah berdasarkan penilaian guru terhadap uji coba buku teks sastra berbasis kearifan lokal Pati sebagai materi pembelajaran bahasa Indonesia meliputi tujuh aspek, yaitu (1) penilaian terhadap kehadiran buku teks sastra berbasis kearifan lokal, (2) peranan buku teks sastra berbasis kearifan lokal dalam membantu pembelajaran sastra, (3) pemenuhan kebutuhan akan buku teks sastra, (4) penilaian isi buku teks sastra berbasis kearifan lokal, (5) penilaian tingkat kesahihan (validitas) materi dalam buku teks sastra berbasis kearifan lokal, (6) penilaian kemampuan buku teks sastra berbasis kearifan lokal untuk dipahami, dan (7) kritik dan saran secara umum mengenai buku teks sastra berbasis kearifan lokal.

\section{A. Hasil Analisis Kebutuhan Buku Teks Sastra Berbasis Kearifan Lokal Pati sebagai Materi Pembelajaran Bahasa Indonesia}

Aspek kedua ini membahas kebutuhan Buku Teks Sastra berbasis Kearifan Lokal Pati sebagai Materi Pembelajaran Bahasa Indonesia. Untuk mengetahui kebutuhan buku teks sastra, aspek ini dijabarkan dalam dua indikator, yaitu (1) peran kehadiran buku teks, (2) model buku teks sastra yang dibutuhkan. Gambaran analisis kebutuhan tentang perlu/tidaknya buku teks sastra dapat dilihat pada tabel $4.1 \mathrm{di}$ bawah ini.

Tabel 4.1 Kebutuhan Buku Teks Sastra Berbasis Kearifan Lokal Pati sebagai Materi Pembelajaran Bahasa Indonesia

\begin{tabular}{|c|c|c|c|}
\hline Indikator & $\begin{array}{c}\text { Jumla } \\
\text { h Guru }\end{array}$ & Jawaban & $\begin{array}{c}\text { Intensita } \\
\text { s } \\
\text { Jawaban }\end{array}$ \\
\hline $\begin{array}{l}\text { Pendapat } \\
\text { guru }\end{array}$ & 15 guru & $\begin{array}{l}\text { Sangat } \\
\text { penting }\end{array}$ & $\begin{array}{l}1 \\
3\end{array}$ \\
\hline terhadap & & Penting & 2 \\
\hline $\begin{array}{l}\text { kehadiran } \\
\text { buku teks } \\
\text { sastra }\end{array}$ & & $\begin{array}{l}\text { Kurang } \\
\text { penting }\end{array}$ & 0 \\
\hline
\end{tabular}




\begin{tabular}{|c|c|c|c|}
\hline 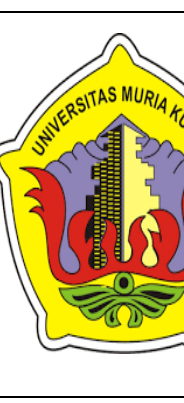 & \multicolumn{3}{|c|}{$\begin{array}{r}\text { Kredo } 4 \\
\text { KREDO: Jurnal Ilmial } \\
\text { Terakreditasi Sinta } 4 \text { be } \\
\text { Direktorat Jenderal P } \\
\text { Pengembangan, Kementer } \\
\text { Pendidikan Tinggi R } \\
\text { Nomor: 23/E/KPT/201 } \\
\text { https://jurnal.umk.ac.id/i }\end{array}$} \\
\hline \multirow[t]{4}{*}{$\begin{array}{l}\text { Harapan } \\
\text { guru } \\
\text { terhadap } \\
\text { buku teks } \\
\text { yang di- } \\
\text { gunakan } \\
\text { guru dalam } \\
\text { pembelajara } \\
\text { n sastra }\end{array}$} & \multirow[t]{4}{*}{15 guru } & $\begin{array}{l}\text { Buku teks } \\
\text { yang } \\
\text { menyajikan } \\
\text { materi sastra } \\
\text { secara } \\
\text { lengkap }\end{array}$ & 8 \\
\hline & & $\begin{array}{l}\text { Diselingi } \\
\text { gambar } \\
\text { ilustrasi } \\
\text { sehingga } \\
\text { mempermuda } \\
\text { h } \\
\text { imajinasi }\end{array}$ & 8 \\
\hline & & $\begin{array}{l}\text { Menyertakan } \\
\text { contoh teks } \\
\text { sastra, lebih } \\
\text { dari satu teks }\end{array}$ & $\begin{array}{l}1 \\
0\end{array}$ \\
\hline & & $\begin{array}{l}\text { Membantu } \\
\text { menuntun } \\
\text { dalam } \\
\text { memproduksi } \\
\text { teks sastra }\end{array}$ & 4 \\
\hline
\end{tabular}

Berdasarkan tabel 4.1 dapat dideskripsikan bahwa 15 guru yang menjadi subjek analisis kebutuhan pengembangan buku teks sastra berbasis kearifan lokal, sebagian besar menganggap kehadiran buku teks sastra sangat penting. Hal ini dibuktikan dengan 13 guru menjawab sangat penting, 2 guru menjawab penting, dan tidak terdapat guru yang menjawab kurang penting. Guru memang sudah mendapatkan sarana belajar berupa buku teks paket dari pemerintah, namun buku teks tersebut dirasa sangat kurang dalam memenuhi kebutuhan pembelajaran. Hal tersebut dirasakan oleh hampir semua guru. Guru merasa membutuhkan referensi tambahan pada setiap matapelajarannya. Bagi sebagian guru, sastra menjadi hal yang sangat sulit untuk diajarkan pada siswa. Sebelumnya sebagian besar guru menyampaikan sudah menggunakan tambahan sebagai referensi, berupa buku teks Bahasa Indonesia, yang di dalamnya membahas sastra dan kebahasaan secara bersamaan. Sedangkan buku teks sastra yang peneliti rancang ini tergolong dalam buku yang bersifat lebih khusus lagi, dengan adanya buku teks sastra ini diharapkan guru tahu lebih banyak mengenai sastra sehingga memudahkan dalam melaksanakan pembelajaran.

\section{B. Hasil Validasi Ahli terhadap Buku Teks Sastra Berbasis Kearifan Lokal Pati sebagai Materi Pembelajaran Bahasa Indonesia \\ Validasi ahli terhadap Buku Teks} Sastra Berbasis Kearifan Lokal Pati sebagai Materi Pembelajaran Bahasa Indonesia meliputi empat aspek, yaitu (1) desain sampul buku teks Sastra Berbasis Kearifan Lokal, (2) isi dan desain buku teks Sastra Berbasis Kearifan Lokal dalam membantu pembelajaran sastra, (3) bahasa dan keterbacaan buku teks Sastra Berbasis Kearifan Lokal, (4) grafika buku teks Sastra Berbasis Kearifan Lokal.

Berikut pemaparan keempat aspek tersebut dapat dilihat pada tabel 4.2 di bawah ini. 


Kredo 4 (2021)
KREDO: Jurnal Ilmiah Bahasa dan Sastra
Terakreditasi Sinta 4 berdasarkan Keputusan
Direktorat Jenderal Penguatan Riset dan
Pengembangan, Kementerian Riset, Teknologi dan
Pendidikan Tinggi Republik Indonesia
Nomor: 23/E/KPT/2019.08 Agustus 2019
https://jurnal.umk.ac.id/index.php/kredo/index

Tabel 4.2 Hasil Validasi Ahli terhadap Buku Teks Sastra Berbasis Kearifan Lokal Pati sebagai Materi Pembelajaran Bahasa Indonesia

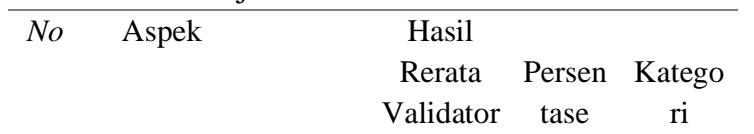

(\%)

\begin{tabular}{|c|c|c|c|c|}
\hline 1 & $\begin{array}{l}\text { Desain sampul } \\
\text { buku teks Sastra } \\
\text { Berbasis } \\
\text { Kearifan Lokal }\end{array}$ & 49,83 & 83,06 & Baik \\
\hline 2 & $\begin{array}{l}\text { Isi dan desain } \\
\text { buku teks Sastra } \\
\text { Berbasis } \\
\text { Kearifan Lokal } \\
\text { dalam } \\
\text { membantu } \\
\text { pembelajaran } \\
\text { sastra }\end{array}$ & 51,22 & 85,37 & $\begin{array}{l}\text { Sangat } \\
\text { Baik }\end{array}$ \\
\hline 3 & $\begin{array}{l}\text { Bahasa dan } \\
\text { keterbacaan buku } \\
\text { teks Sastra } \\
\text { Berbasis } \\
\text { Lokarifan }\end{array}$ & 50,78 & 84,63 & $\begin{array}{l}\text { Sangat } \\
\text { Baik }\end{array}$ \\
\hline 4 & $\begin{array}{l}\text { Grafika } \\
\text { u buk } \\
\text { sastra berbasis } \\
\text { Kearifan Lokal }\end{array}$ & 51,83 & 86,39 & $\begin{array}{l}\text { Sangat } \\
\text { Baik }\end{array}$ \\
\hline
\end{tabular}

Dari tabel 4.2 dapat dideskripsikan hasil validasi ahli terhadap Buku Teks Sastra Berbasis Kearifan Lokal Pati sebagai Materi Pembelajaran Bahasa Indonesia sebagai berikut. Pada aspek pertama mengenai desain sampul, buku teks Sastra Berbasis Kearifan Lokal mendapat hasil rerata 49,83 atau setara dengan nilai presentase $83,06 \%$, hasil ini menunjukkan desain sampul buku teks Sastra Berbasis Kearifan Lokal masuk pada kategori baik.

Pada aspek kedua mengenai isi dan desain, buku teks Sastra Berbasis
Kearifan Lokal mendapat hasil rerata 51,22 atau setara dengan nilai presentase $85,37 \%$, hasil ini menunjukkan isi dan desain buku teks Sastra Berbasis Kearifan Lokal masuk pada kategori sangat baik.

Pada aspek ketiga mengenai bahasa dan keterbacaan, buku teks Sastra Berbasis Kearifan Lokal mendapat hasil rerata 50,78 atau setara dengan nilai presentase $84,63 \%$, hasil ini menunjukkan bahasa dan keterbacaan buku teks Sastra Berbasis Kearifan Lokal masuk pada kategori sangat baik.

Pada aspek ketiga mengenai grafika, buku teks Sastra Berbasis Kearifan Lokal mendapat hasil rerata 51,83 atau setara dengan nilai presentase $86,39 \%$, hasil ini menunjukkan grafika buku teks Sastra Berbasis Kearifan Lokal masuk pada kategori sangat baik.

Dari hasil validasi di atas, dapat dilihat bahwa buku teks Sastra Berbasis Kearifan Lokal sudah nyatakan layak karena buku teks Sastra Berbasis Kearifan Lokal telah memenuhi standar validitas meskipun tetap akan diadakan revisi-revisi pada beberapa bagian guna menyempurnakan produk.

\section{Penilaian dan Saran Perbaikan terhadap Buku Teks Sastra Berbasis Kearifan Lokal Pati sebagai Materi Pembelajaran Bahasa Indonesia berdasarkan Validasi Ahli}

Setelah menyusun buku teks Sastra Berbasis Kearifan Lokal Pati, 

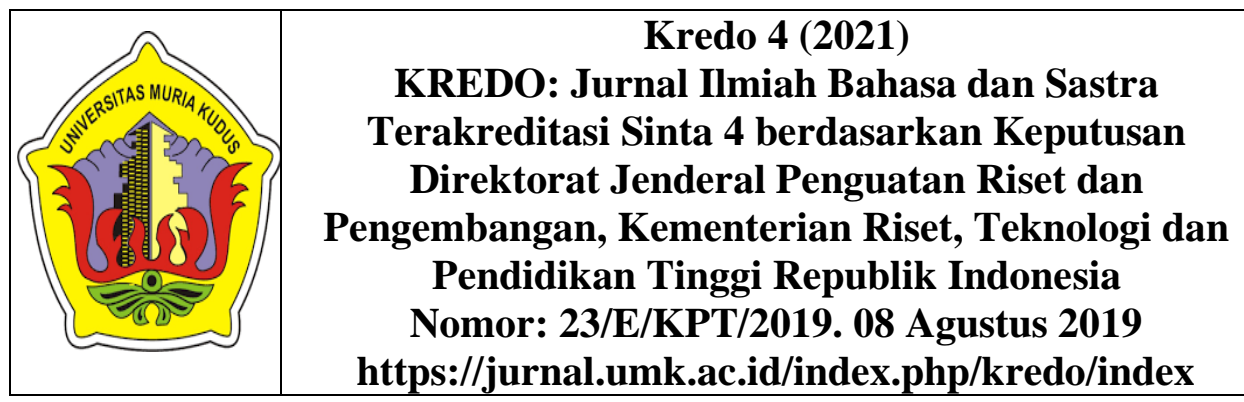

KREDO: Jurnal Ilmiah Bahasa dan Sastra Terakreditasi Sinta 4 berdasarkan Keputusan Direktorat Jenderal Penguatan Riset dan Pengembangan, Kementerian Riset, Teknologi dan Pendidikan Tinggi Republik Indonesia Nomor: 23/E/KPT/2019. 08 Agustus 2019 https://jurnal.umk.ac.id/index.php/kredo/index

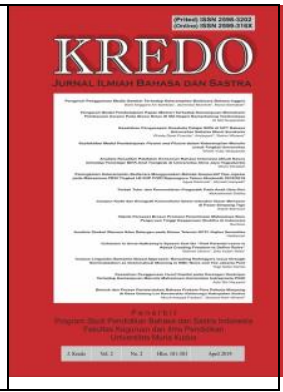

langkah selanjutnya adalah melakukan penilaian terhadap buku teks Sastra Berbasis Kearifan Lokal Pati. Berdasarkan pengamatan yang dilakukan kepada tiga orang ahli, didapatkan hasil penelitian sebagai berikut.

\section{Sampul Buku teks}

Penilaian sampul Sastra Berbasis Kearifan Lokal memperoleh nilai ratarata dari ahli sebesar 85,06. Berdasarkan penilaian ini, dapat disimpulkan bahwa desain sampul sudah tergolong sangat baik. Sampul yang disajikan peneliti sudah sesuai untuk mengilustrasikan isi dari buku teks.

Selain penilaian tersebut, terdapat beberapa saran perbaikan untuk sampul buku teks, yaitu sampul depan sebaiknya ditambah dengan 1 gambar yang merupakan ikon Pati.

Berikut Perbaikan pada sampul berdasarkan validasi ahli dapat dilihat pada gambar 4.2.

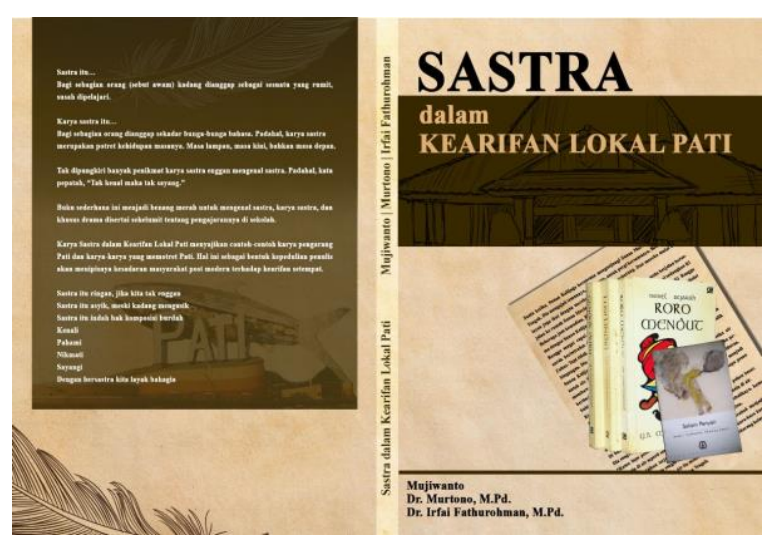

Gambar 4.2 Sampul Buku Teks Sastra Pascavalidasi Ahli

437 | Jurnal Kredo

Vol. 4 No. 22021

\section{Isi dan Desain Buku Teks} Sastra Berbasis Kearifan Lokal Pati

Dimensi isi dan format sajian Sastra Berbasis Kearifan Lokal Pati memperoleh nilai rata-rata dari ahli sebesar 85,37. Dari penilaian ini, dimensi isi dan format sajian Sastra Berbasis Kearifan Lokal Pati yang dibuat peneliti sudah dinilai sangat baik.

Selain penilain tersebut, ada beberapa saran perbaikan untuk dimensi isi dan desain Buku Teks Sastra Berbasis Kearifan Lokal, yaitu ditambahkan gambar ilustrasi pada materi yang sesuai.

3. Bahasa dan Keterbacaan Buku Teks Sastra Berbasis Kearifan Lokal Pati

Pada aspek bahasa dan keterbacaan Sastra Berbasis Kearifan Lokal Pati mendapat penilaian rata-rata dari ahli sebesar 84,63. Dari penilaian ini, aspek bahasa dan keterbacaan buku teks Sastra Berbasis Kearifan Lokal Pati yang dibuat peneliti sudah dinilai baik. Bahasa dan keterbacaan dinilai dapat menunjukkan ketercapaian penyampaian pesan, sehingga tidak ada saran perbaikan yang sifatnya meminta pengkonstruksian ulang.

\section{Grafika}

Grafika pada Sastra Berbasis Kearifan Lokal memperoleh nilai ratarata dari ahli sebesar 86,39. Dari penilaian ini, aspek tata letak, 


Kredo 4 (2021)
KREDO: Jurnal Ilmiah Bahasa dan Sastra
Terakreditasi Sinta 4 berdasarkan Keputusan
Direktorat Jenderal Penguatan Riset dan
Pengembangan, Kementerian Riset, Teknologi dan
Pendidikan Tinggi Republik Indonesia
Nomor: 23/E/KPT/2019.08 Agustus 2019
https://jurnal.umk.ac.id/index.php/kredo/index

sistematika, dan ukuran buku teks Sastra Berbasis Kearifan Lokal Pati yang dibuat peneliti sudah dinilai baik. Tata letak, sistematika, dan ukuran dinilai sudah memenuhi kriteria.

\section{Saran Perbaikan secara Umum terhadap Buku Teks Sastra Berbasis Kearifan Lokal Pati}

Secara umum, ada beberapa saran perbaikan yang diberikan oleh ahli terhadap buku teks Sastra Berbasis Kearifan Lokal Pati, yaitu perbaikan pada beberapa diksi pada sampul belakang dan beberapa bagian isi buku.

\section{Hasil Penilaian Guru terhadap} Uji Coba Buku Teks Sastra Berbasis Kearifan Lokal Pati sebagai Materi Pembelajaran Bahasa Indonesia

Penilaian guru terhadap uji coba Buku Teks Sastra Berbasis Kearifan Lokal Pati sebagai Materi Pembelajaran Bahasa Indonesia meliputi empat aspek, yaitu (1) penilaian terhadap kehadiran buku teks Sastra Berbasis Kearifan Lokal, (2) peranan buku teks Sastra Berbasis Kearifan Lokal dalam membantu pembelajaran sastra, (3) pemenuhan kebutuhan akan buku teks sastra, (4) penilaian isi dari buku teks Sastra Berbasis Kearifan Lokal, (5) penilaian tingkat kesalihan (valid) materi dalam buku teks Sastra Berbasis Kearifan Lokal, (6) penilaian kemampuan buku teks Sastra Berbasis
Kearifan Lokal untuk dipahami, dan (7) kritik dan saran secara umum mengenai buku teks Sastra Berbasis Kearifan Lokal. Pemaparan ketujuh aspek tersebut dapat dilihat pada tabel 4.6

Tabel 4.3 Hasil Penilaian Guru terhadap Uji Coba Buku Teks Sastra Berbasis Kearifan Lokal Pati sebagai Materi Pembelajaran Bahasa Indonesia

\begin{tabular}{|c|c|c|c|}
\hline Indikator & $\begin{array}{c}\text { Jumla } \\
h \\
\text { Guru }\end{array}$ & Jawaban & $\begin{array}{c}\text { Intensit } \\
\text { as } \\
\text { Jawaba } \\
n\end{array}$ \\
\hline $\begin{array}{l}\text { Penilaian } \\
\text { terhadap } \\
\text { urgensi } \\
\text { kehadiran } \\
\text { buku teks } \\
\text { sastra } \\
\text { berbasis } \\
\text { kearifan } \\
\text { lokal Pati }\end{array}$ & $\begin{array}{c}10 \\
\text { guru }\end{array}$ & $\begin{array}{l}\text { Sangat baik } \\
\text { Baik } \\
\text { Cukup }\end{array}$ & $\begin{array}{c}10 \\
0 \\
0\end{array}$ \\
\hline $\begin{array}{lr}\begin{array}{l}\text { Peranan } \\
\text { teks }\end{array} & \text { buku } \\
\text { berbasis } & \\
\text { kearifan lokal } \\
\text { Pati dalam } \\
\text { membantu } \\
\text { pembelajaran } \\
\text { sastra }\end{array}$ & $\begin{array}{c}10 \\
\text { guru }\end{array}$ & $\begin{array}{l}\text { Sangat baik } \\
\text { Baik } \\
\text { Cuku } \\
\text { p } \\
\text { Tidak baik }\end{array}$ & $\begin{array}{l}6 \\
4 \\
0\end{array}$ \\
\hline $\begin{array}{l}\text { Pemenuhan } \\
\text { kebutuhan } \\
\text { akan buku } \\
\text { teks sastra }\end{array}$ & $\begin{array}{c}10 \\
\text { guru }\end{array}$ & $\begin{array}{l}\text { Sangat baik } \\
\text { Baik } \\
\text { Cukup } \\
\text { Tidak baik }\end{array}$ & $\begin{array}{l}5 \\
5 \\
0 \\
0\end{array}$ \\
\hline $\begin{array}{l}\text { Penilaian isi } \\
\text { dari buku teks } \\
\text { sastra berbasis } \\
\text { kearifan lokal } \\
\text { Pati }\end{array}$ & $\begin{array}{l}10 \\
\text { guru }\end{array}$ & $\begin{array}{l}\text { Sangat baik } \\
\text { Baik } \\
\text { Cukup } \\
\text { Tidak baik }\end{array}$ & $\begin{array}{l}9 \\
1 \\
0 \\
0\end{array}$ \\
\hline
\end{tabular}




\begin{tabular}{|c|c|c|c|}
\hline$\sqrt{\frac{5}{40}}$ & & $\begin{array}{l}\text { KREDO: } \\
\text { rakredits } \\
\text { Direktor: } \\
\text { embanga } \\
\text { Pendidi } \\
\text { Nomor: } 2 \\
\text { ps://jurn: }\end{array}$ & $\begin{array}{l}\text { Kred } \\
\text { nal Ilr } \\
\text { Sinta } \\
\text { ender } \\
\text { Kemen } \\
\text { Ting } \\
\text { /KPT } \\
\text { mk.ac }\end{array}$ \\
\hline \multirow[t]{2}{*}{$\begin{array}{l}\text { Penilaian } \\
\text { tingkat } \\
\text { kesalihan } \\
\text { (valid) materi } \\
\text { dalam buku teks } \\
\text { Sastra Berbasis } \\
\text { Kearifan Lokal } \\
\text { Pati }\end{array}$} & \multirow[t]{2}{*}{$\begin{array}{c}10 \\
\text { guru }\end{array}$} & $\begin{array}{l}\text { Sangat baik } \\
\text { Baik }\end{array}$ & $\begin{array}{l}3 \\
7\end{array}$ \\
\hline & & Tidak baik & 0 \\
\hline $\begin{array}{l}\text { Penilaian } \\
\text { kemampuan } \\
\text { buku teks sastra } \\
\text { berbasis } \\
\text { kearifan lokal } \\
\text { Pati untuk } \\
\text { dipahami }\end{array}$ & $\begin{array}{c}10 \\
\text { guru }\end{array}$ & $\begin{array}{l}\text { Sangat baik } \\
\text { Baik } \\
\text { Cukup }\end{array}$ & $\begin{array}{l}5 \\
5 \\
0\end{array}$ \\
\hline
\end{tabular}

Berdasarkan tabel 4.3 dapat dideskripsikan hasil penilaian guru terhadap uji coba buku teks sastra berbasis kearifan lokal Pati sebagai materi pembelajaran bahasa Indonesia sebagai berikut. Indikator pertama merupakan penilaian terhadap kehadiran buku teks sastra berbasis kearifan lokal, hasilnya 10 guru menjawab sangat baik dengan memberikan saran agar buku tersebut dapat segera digunakan.

Pada penilaian berikutnya yakni mengenai peranan buku teks sastra berbasis kearifan lokal dalam membantu pembelajaran sastra, hasilnya 6 guru menyatakan sangat baik dan 4 guru menyatakan baik. Guru menyampaikan bahwa buku teks tersebut cukup membantu guru dalam melaksanakan pembelajaran sastra. Guru juga merasa memiliki cukup referensi materi dan contoh teks sastra.

Penilaian berikutnya adalah penilaian mengenai pemenuhan kebutuhan akan buku teks sastra. Hasilnya 5 guru menilai sangat baik dan 5 guru menilai baik. Sebagian besar guru menyampaikan bahwa kehadiran buku teks sastra tersebut telah mengisi kekosongan referensi khususnya sastra bagi guru.

Selanjutnya penilaian mengenai isi dari buku teks Sastra berbasis kearifan lokal. Sejumlah 9 guru menilai sangat baik, mereka menyampaikan bahwa isi buku teks sastra tersebut memenuhi seluruh materi yang diajarkan di SMP/MTs, sedangkan 1 guru menilai baik. Beberapa guru menyarankan untuk ditambahkannya gambar pada tiap-tiap contoh teks sastra untuk memudahkan pengimajian.

Pada penilaian berikutnya dikaji mengenai tingkat kesahihan (validitas) materi dalam buku teks sastra berbasis kearifan lokal Pati. Sejumlah 3 guru menilai sangat baik dan 7 guru menilai baik. Hal ini menunjukkan kesahihan materi di dalam buku teks dianggap sudah memenuhi legalitas.

Penilaian terakhir yaitu penilaian mengenai kemampuan buku teks sastra berbasis kearifan lokal Pati untuk dipahami. Sejumlah 5 guru mengungkapkan bahwa buku teks sangat baik untuk dipahami. Sejumlah 5 guru lainnya menilai buku teks sastra berbasis kearifan lokal baik untuk dipahami. Saran yang guru sampaikan mengenai kemampuan untuk dipahami, sebaiknya penulis menjelaskan lebih

\section{9 | Jurnal Kredo}

Vol. 4 No. 22021 


Kredo 4 (2021)
KREDO: Jurnal Ilmiah Bahasa dan Sastra
Terakreditasi Sinta 4 berdasarkan Keputusan
Direktorat Jenderal Penguatan Riset dan
Pengembangan, Kementerian Riset, Teknologi dan
Pendidikan Tinggi Republik Indonesia
Nomor: 23/E/KPT/2019.08 Agustus 2019
https://jurnal.umk.ac.id/index.php/kredo/index

sederhana lagi sehingga buku juga bisa lebih efektif digunakan siswa.

\section{E. Hasil Perbaikan Buku Teks Sastra Berbasis Kearifan Lokal Pati Berdasarkan Uji Coba Produk}

Setelah melalui pengujicobaan buku teks, didapatkan hasil penilaian dan masukan sebagai dasar perbaikan Buku Teks Sastra Berbasis Kearifan Lokal Pati. Akan tetapi, tidak semua saran masukan yang didapat, dijadikan sebagai dasar perbaikan karena peneliti mempunyai konsep dan pertimbangan sendiri. Berikut hasil perbaikan buku teks Sastra Berbasis Kearifan Lokal sebagai Materi Pembelajaran Bahasa Indonesia di SMP/MTs.

\section{Sampul}

Perbaikan yang dilakukan pada sampul adalah perubahan jenis huruf pada judul buku dan penambahan gambar Pintu Gerbang Majapahit sebagai artefak yang menjadi ikon kearifan lokal Pati.

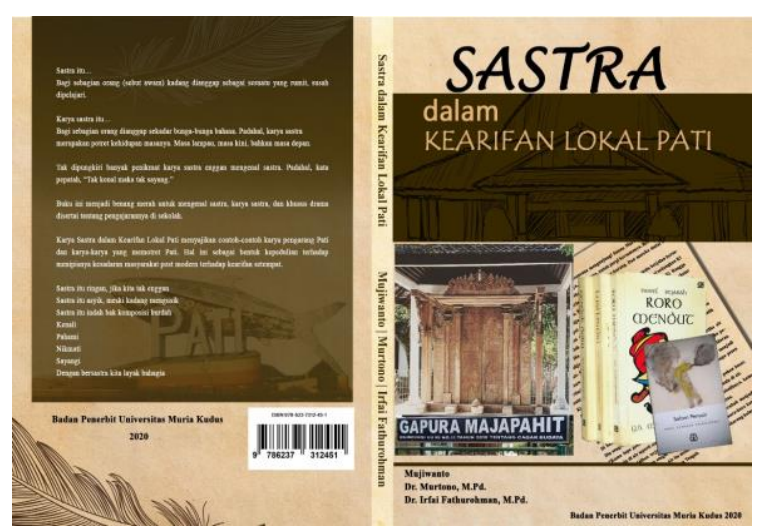

Gambar 4.3 Perbaikan Sampul Buku Teks Sastra Berbasis Kearifan Lokal Pascauji Coba

\section{Isi dan Desain Buku Teks Sastra Berbasis Kearifan Lokal Pati}

Berdasarkan uji coba oleh guru SMP/MTs isi dan desain sudah memenuhi dan mencakup seluruh indikator sebagai buku teks. Bahasa dan keterbacaan dinilai mendapatkan ketercapaian penyampaian pesan, sehingga tidak ada saran perbaikan yang sifatnya meminta pengkonstruksian ulang.

\section{SIMPULAN}

Berdasarkan uraian hasil penelitian dan pembahasan dapat dikemukakan simpulan yang berkaitan dengan pengembangan Buku Teks Sastra Berbasis Kearifan Lokal Pati sebagai Materi Pembelajaran Bahasa Indonesia di SMP/MTs sebagai berikut.

Pertama, berdasarkan analisis kebutuhan Buku Teks Sastra Berbasis Kearifan Lokal Pati sebagai Materi Pembelajaran Bahasa Indonesia, guru membutuhkan buku teks sastra yang mengandung unsur pendidikan karakter kearifan lokal. Buku teks yang diinginkan oleh guru sebagai referensi pembelajaran sastra adalah buku teks yang mencukupi, melingkupi, dan sesuai dengan materi pembelajaran sastra di SMP/MTs. Buku Teks Sastra Berbasis 


Kredo 4 (2021)
KREDO: Jurnal Ilmiah Bahasa dan Sastra
Terakreditasi Sinta 4 berdasarkan Keputusan
Direktorat Jenderal Penguatan Riset dan
Pengembangan, Kementerian Riset, Teknologi dan
Pendidikan Tinggi Republik Indonesia
Nomor: 23/E/KPT/2019. 08 Agustus 2019
https://jurnal.umk.ac.id/index.php/kredo/index

Kearifan Lokal Pati sebagai materi Pembelajaran Bahasa Indonesian ini sangat bermanfaat sebagai penanaman nilai-nilai kearifan lokal pada siswa SMP/MTs.

Kedua, berdasarkan validasi, penilaian, dan saran perbaikan prototipe buku teks Sastra Berbasis Kearifan Lokal oleh ahli dengan rentang nilai $1-4$, dengan penskoran 15 sampai dengan 60, diperoleh skor rata-ratanya adalah 49,83 atau setara dengan nilai presentase $83,06 \%$ untuk sampul buku teks Sastra Berbasis Kearifan Lokal, 51,22 atau setara dengan nilai presentase $85,06 \%$ untuk isi dan desain buku teks Sastra Berbasis Kearifan Lokal, 50,78 atau setara dengan nilai presentase $84,63 \%$ untuk bahasa dan keterbacaan buku teks Sastra Berbasis Kearifan Lokal, dan 50,78 atau setara dengan nilai presentase $84,63 \%$ untuk grafika buku teks Sastra Berbasis Kearifan Lokal. Sehingga buku teks Sastra Berbasis Kearifan Lokal dinyatakan layak dan valid.

Ketiga, berdasarkan hasil penilaian uji coba yang dilakukan oleh guru, dapat dilihat bahwa buku teks Sastra Berbasis Kearifan Lokal sangat diharapkan keberadaannya, guru berharap buku tersebut dapat segera digunakan. Guru merasa terbantu dengan adanya buku teks Sastra Berbasis
Kearifan Lokal sebagai referensi penunjang dalam pembelajaran. Mengenai isi, guru menyampaikan bahwa materi di dalam buku teks dianggap telah memenuhi seluruh materi yang diajarkan di SMP/MTs. Sedangkan kesahihan materi di dalam buku teks dianggap sudah memenuhi legalitas. Kajian terakhir yakni mengenai kemampuan buku teks Sastra Berbasis Kearifan Lokal untuk dipahami, pada kajian ini guru menilai buku teks Sastra Berbasis Kearifan Lokal baik untuk dipahami.

Dari data di atas buku teks Sastra Berbasis Kearifan Lokal Pati sebagai Materi Pembelajaran Bahasa Indonesia di SMP/MTs telah menjadi sebuah produk yang baik, layak, dan dapat memenuhi kebutuhan guru SMP/MTs. 


Kredo 4 (2021)
KREDO: Jurnal Ilmiah Bahasa dan Sastra
Terakreditasi Sinta 4 berdasarkan Keputusan
Direktorat Jenderal Penguatan Riset dan
Pengembangan, Kementerian Riset, Teknologi dan
Pendidikan Tinggi Republik Indonesia
Nomor: 23/E/KPT/2019.08 Agustus 2019
https://jurnal.umk.ac.id/index.php/kredo/index

\section{DAFTAR PUSTAKA}

Fahmy, Zulfa dkk. 2015. Pengembangan Buku Pengayaan Memproduksi Teks Fabel Bermuatan Nilai Budaya untuk Siswa SMP. Seloka. Volume 4, Nomor 2 Tahun 2015.

Kustanto, Hery dan A. Hinduan. 2009. Kecenderungan Buku Teks Fisika Lama dan Buku Teks Fisika Baru untuk SMA. Tesis. Yogyakarta: Program Pasca Sarjana Pendidikan Fisika UAD.

Muslich, Masnur. 2010. Textbook Writing: Dasar-dasar Pemahaman, Penulisan, dan Pemakaian Buku Teks. Yogyakarta: Ar-ruzz Media.

Purwanta, Edi. 2012. Buku Ajar Bimbingan dan Konseling Anak Berkebutuhan Khusus. Yogyakarta: UNY Press.

Sartini. 2004. Menggali Kearifan Lokal Nusantara Sebuah Kajian Filsafati. Jurnal Filsafat. Volume 14, Nomor 2 Tahun 2004.

Sugiyono. 2019. Metode Penelitian dan Pengembangan (Research and Development/RnD). Bandung: Alfabeta.

Sukmadinata, Nana Saodih. 2012. Metode Penelitian Pendidikan. Bandung: Remaja Rosdakarya.

Tarigan, H.G. dan Djago Tarigan. 2009. Telaah Buku Teks Bahasa Indonesia. Bandung: Angkasa.

Warso, Agus Wasisto Dwi Doso. 2016. Publikasi Ilmiah Pembuatan Buku, Modul, Diktat \& Nilai Angka Kreditnya. Yogyakarta: Putaka Pelajar.

Wibowo, Agus dan Gunawan. 2015. Pendidikan Karakter Berbasis Kearifan Lokal di Sekolah. Yogyakarta: Pustaka Pelajar. 